\title{
Contribution of Milkfish Sarcoplasmic Protein to the Thermal Gelation of Myofibrillar Protein
}

\author{
Wen-Ching Ko and Meng-Shan Hwang \\ Department of Food Science, National Chung Hsing University, Kuokuang Road, Taichung, Taiwan, ROC \\ (Received March 15, 1994)
}

This research investigated sarcoplasmic protein $(\mathrm{Sp}-\mathrm{P})$ contribution to the thermal gelation of meat paste and myofibrillar protein. The $\mathrm{Sp}-\mathrm{P}$ was recovered by an ultrafiltration unit from the wash water of milkfish meat paste preparations. Washed meat paste showed gel strength $1.4-2.0$ times that of unwashed paste. This may be caused by the concentration effect of myofibrillar protein. Adding Sp-P increased gel strength in both washed and unwashed meat pastes. The larger the amount of Sp-P added, the stronger the effect. Suwari occurred at $40-50^{\circ} \mathrm{C}$ and modori occurred at $60-70^{\circ} \mathrm{C}$ for milkfish meat pastes irrespective of the addition of Sp-P. Sp-P addition $(10 \mathrm{mg} / \mathrm{g})$ caused suwari indices to change from 41 to 51 , and modori indices from 37 to 33 . These results show that the addition of Sp-P improves thermal gelation, has a promotive effect on suwari and a restrictive effect on modori.

Key words: thermal gelation, sarcoplasmic protein, myofibrillar protein, milkfish

Since water-soluble proteins of fish meat are regarded as a hindrance in gelation, they are generally removed by washing during surimi processing. ${ }^{1-4)}$ The operation increases costs and may also cause water pollution. Some research has indicated that fish water-soluble proteins not only do not interfere with gel-formation of myofibrillar proteins, but also form a gel, if sufficiently concentrated. ${ }^{7)}$ Many methods such as heating, adding chemicals containing acid, alkali or coagulants, and bubble separation have been attempted to recover the proteins from the wastewater. ${ }^{8-13)}$ However, the low level of proteins in large amounts of wastewater makes the above processes uneconomical. These processes may also cause protein denaturing and even secondary contamination. In contrast, an ultrafiltration unit with MWCO 30,000 can be used to recover $70 \%$ of milkfish sarcoplasmic proteins (Sp-P) without denaturation. ${ }^{14)}$ Milkfish is an important fish species cultured in Taiwan. Its dorsal muscles are usually utilized as minced fish raw material and $\mathrm{Sp}-\mathrm{P}$ is lost in wash water during processing. In this study, the recovered $\mathrm{Sp}-\mathrm{P}$ was added to meat pastes to investigate the contribution to thermal gelation. The effect of Sp-P on suwari and modori was also determined.

\section{Materials and Methods}

\section{Materials}

Milkfish Chanos chanos weighing about $600 \mathrm{~g}$ was purchased from a local retail store, and was kept in ice before preparation of test samples. All chemicals used were of reagent grade.

\section{Sarcoplasmic Protein ( $S p-P)$ Preparation}

Ordinary muscle carefully excised from milkfish was minced in a chopper (hole size $3 \mathrm{~mm}$ ). Five vol. of cold phosphate buffer $(I=0.05, \mathrm{pH} 7.0)$ was added to the minced meat, then homogenized for $3 \mathrm{~min}$. The supernatant obtained by centrifugation at $12,000 \times g$ for $15 \mathrm{~min}$ at $4^{\circ} \mathrm{C}$ was collected as $\mathrm{Sp}-\mathrm{P}$ solution.

\section{Myofibrillar Protein Preparation}

The minced milkfish muscle in $0.09 \mathrm{M} \mathrm{KCl}-5 \mathrm{~mm}$ EDTA$0.039 \mathrm{M}$ borate buffer $(\mathrm{pH} 7.0$ ) was homogenized for $5 \mathrm{~min}$. After centrifugation at $10,000 \times g$ for $30 \mathrm{~min}$, the supernatant was discarded. This process was repeated four times. The sediment obtained was used as myofibrillar protein.

\section{Ultrafiltration Operation}

$\mathrm{Sp}-\mathrm{P}$ was recovered and concentrated by an ultrafiltration unit designed by Yeameei Co. of Taiwan. All conditions were the same as that used by Ko et al. ${ }^{14)}$

\section{Meat Paste Preparation}

Fish muscles were minced in a chopper (hole size $3 \mathrm{~mm}$ ), and washed twice with $10 \mathrm{vol}$. of $0.3 \% \mathrm{NaHCO}_{3}-0.15 \%$ $\mathrm{NaCl}$ to remove blood and water-soluble components. It was then centrifuged at $6,500 \times g$ for $60 \mathrm{~min}$ to remove most of the moisture. The washed meat with or without Sp-P addition according to experimental conditions was adjusted at a fixed $\mathrm{pH}$ and desired moisture content. It was then ground manually with $2.5 \% \mathrm{NaCl}$ of the total amount in a mortar at $4^{\circ} \mathrm{C}$ for $10 \mathrm{~min}$ to prepared meat paste.

\section{Thermal Gelation Test}

The meat pastes were sealed in stainless steel tubes (diameter $1.3 \mathrm{~cm} \times$ height $1.3 \mathrm{~cm}$ ), then heated in a water bath at various temperatures.

\section{Gel Strength Measurement}

A rheometer (San Kagaku CR-200D, Japan) with a ball type plunger of diameter $0.7 \mathrm{~cm}$, table speed of $10 \mathrm{~cm} / \mathrm{min}$ and force of $2,000 \mathrm{~g}$ was used. The gel strength was defined as the maximum stress ( $\mathrm{g}$ ) at the breaking point of a sample. Each measurement was made on five samples. Data were analyzed using the Statistical Analysis System. ${ }^{15)}$ The General Linear Model procedure for regression analyses, 
ANOVA procedure for analysis of variance and Duncan's multiple range test for ranking the means were used.

\section{Setting Index and Disintegration Index Calculation}

Setting and disintegration indices were calculated according to the equation of Shimizu et al. as follows: ${ }^{16)}$

Setting index $=$ G.S $S_{40^{\circ} \mathrm{C}, 2 \mathrm{~h}} / \mathrm{G} \cdot \mathrm{S}_{60^{\circ} \mathrm{c}, 20 \mathrm{~min}}$

Disintegration index

$$
=\left(1-\mathrm{G} . \mathrm{S}_{60}{ }^{\circ} \mathrm{C}, 2 \mathrm{~h} / \mathrm{G} \cdot \mathrm{S}_{60^{\circ} \mathrm{C}, 20 \mathrm{~min}}\right) \times 100
$$

G.S $=$ gel strength

\section{Protein Determination}

Protein concentration was determined by the biuret method with calibration using the Kjeldahl method. ${ }^{17)}$

\section{Results and Discussion}

Washed and unwashed meat pastes were adjusted to $80 \%$ moisture content and $\mathrm{pH} 6.8$ with the addition of $2.5 \%$ $\mathrm{NaCl}$. As shown in Fig. 1, the gel strength for washed meat pastes was 1.4-2.0 times that of unwashed paste. In the production of surimi, fish meat is generally washed to improve the gel strength and to obtain a good whiteness. ${ }^{5)}$ The increase in gel strength is due to the concentration of myofibrillar proteins rather than Sp-P removal.

$\mathrm{Sp}-\mathrm{P}$ dissolved in the wash water was recovered by an ultrafiltration unit with a membrane of MWCO 30,000 . The effect of Sp-P on the gel strength of washed and unwashed milkfish meat pastes was investigated. Whether the meat

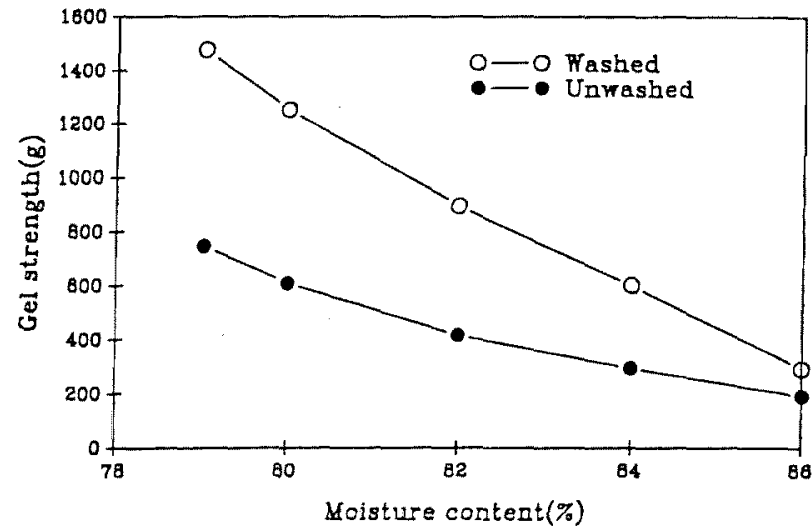

Fig. 1. Relationship between gel strength and moisture content of washed and unwashed milkfish meat paste.

Heating condition: $90^{\circ} \mathrm{C}, 20 \mathrm{~min}$.

Table 1. Effect of sarcoplasmic protein (Sp-P) on the gel strength of washed and unwashed milkfish meat pastes*

\begin{tabular}{ccc}
\hline & \multicolumn{2}{c}{ Gel strength $(\mathrm{g})$} \\
\cline { 2 - 3 } Treatment & Washed & Unwashed \\
\hline Sp-P addition $(3.2 \mathrm{mg} / \mathrm{g})$ & $675.6^{\mathrm{a}}$ & $436.6^{\mathrm{c}}$ \\
Water addition & $593.2^{\mathrm{b}}$ & $342.8^{\mathrm{d}}$ \\
\hline
\end{tabular}

* Minced meat pastes (moisture content $83 \%, \mathrm{pH} 6.8, \mathrm{NaCl} 2.5 \%$ ) were treated at $90^{\circ} \mathrm{C}$ for $20 \mathrm{~min}$ before measuring gel strength

a-t Means not followed by the same letter are significantly different from each other by Duncan's Multiple Range Test at the $p<0.05$ level pastes were washed or not, as shown in Table 1, gel strength clearly increased. Though there is no significant difference in breaking strain, Figs. 2 and 3 show that the higher the Sp-P concentration, the higher the gel strength for both meat pastes and myofibrillar proteins.

Figure 4 shows that, for milkfish meat pastes, suwari, a setting pheonomenon, occurred at $40-50^{\circ} \mathrm{C}$, and modori, a disintegration phenomenon, occurred at $60-70^{\circ} \mathrm{C}$. The temperature ranges of suwari and modori were not affected by the content of Sp-P in the meat pastes.

Figure 5 shows the temperature-gelation curves of washed milkfish meat pastes with or without $\mathrm{Sp}-\mathrm{P}$ addition. A suwari index of 41 at $40^{\circ} \mathrm{C}$ and a modori index of 37 at $60^{\circ} \mathrm{C}$ were obtained for the meat paste without $\mathrm{Sp}-\mathrm{P}$ addition. As also shown in Fig. 5, the index of meat pastes with Sp-P addition $(10 \mathrm{mg} / \mathrm{g})$ changed from 41 to 51 and from 37 to 33 for suwari and modori, respectively. The finding shows the promotion effects by Sp-P on suwari and minor inhibition effects on modori.

The Sp-P not only had no effect on the temperature range for gelation of milkfish meat paste, but also contributed to its thermal gelation properties. This probably results from

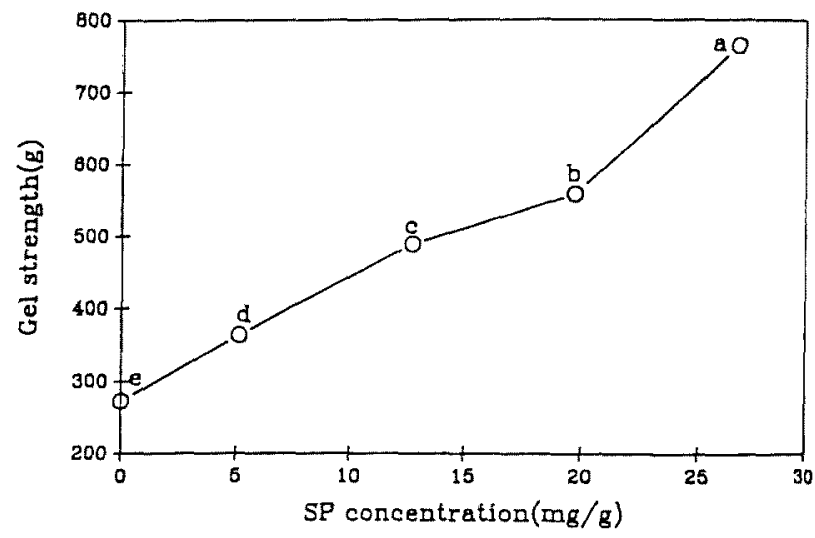

Fig. 2. Effect of sarcoplasmic protein concentrate on gel strength of washed milkfish meat paste.

Heating condition: $90^{\circ} \mathrm{C}, 20 \mathrm{~min}$

Different letters (a-e) adjacent to a value indicate a significant difference $(p<0.05)$ among values.

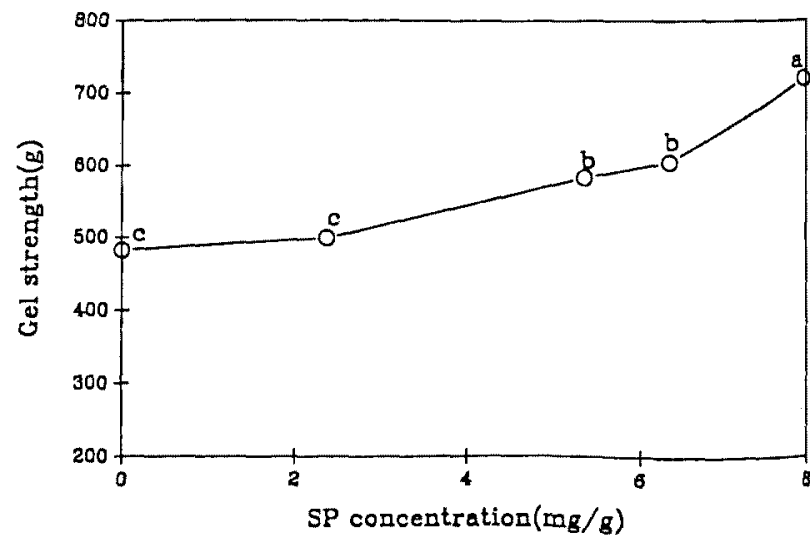

Fig. 3. Effect of sarcoplasmic protein concentrate on gel strength of myofibrillar protein.

Heating condition: $90^{\circ} \mathrm{C}, 20 \mathrm{~min}$.

Different letters (a-e) adjacent to a value indicate a significant difference $(p<0.05)$ among values. 


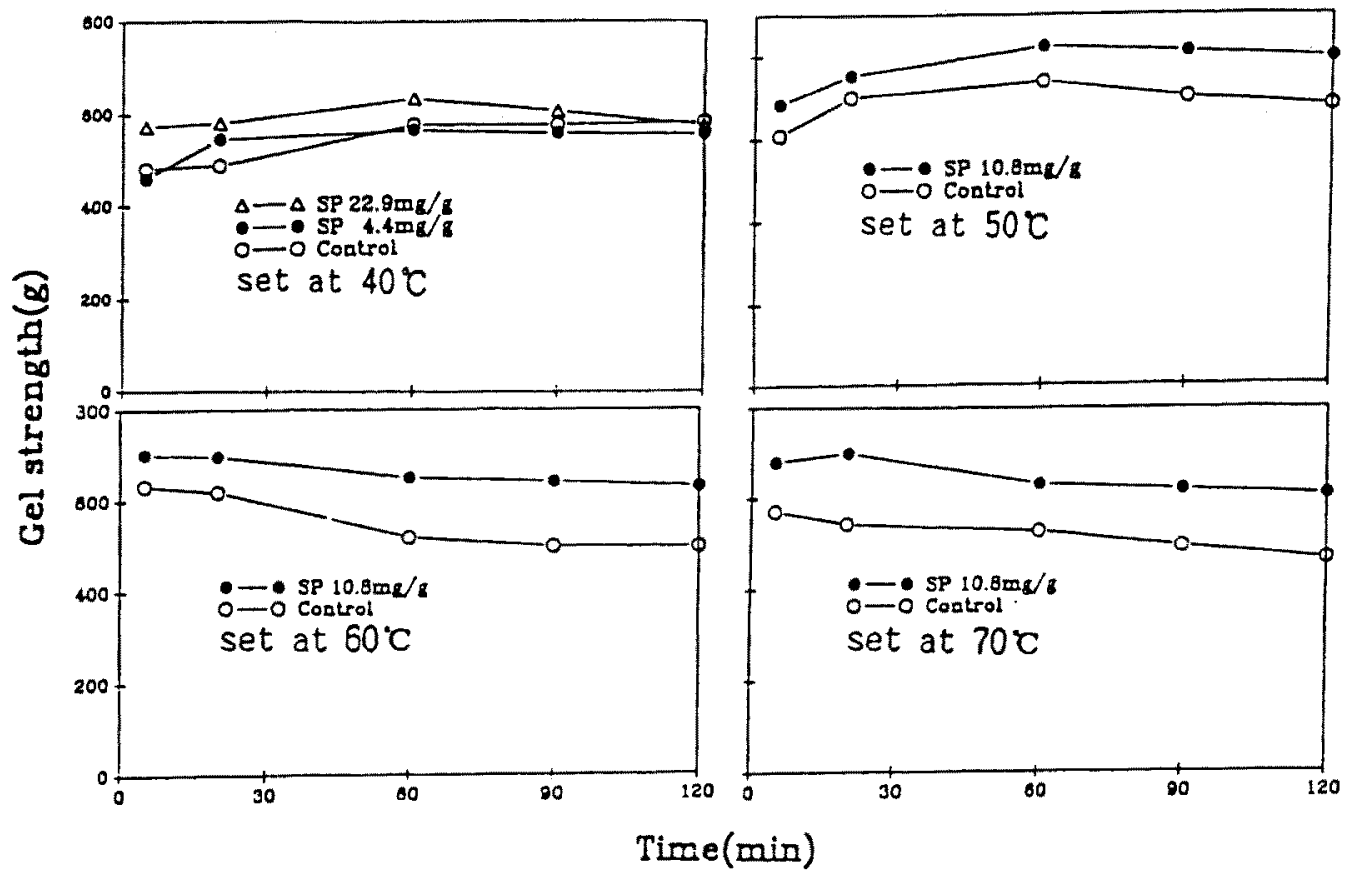

Fig. 4. Effect of setting temperature and time on gel strength of washed milkfish meat paste. The meat pastes (moisture content $83 \%, \mathrm{pH} 6.8, \mathrm{NaCl} 2.5 \%$ ) were set at $40-70^{\circ} \mathrm{C}$ for $5-120 \mathrm{~min}$.

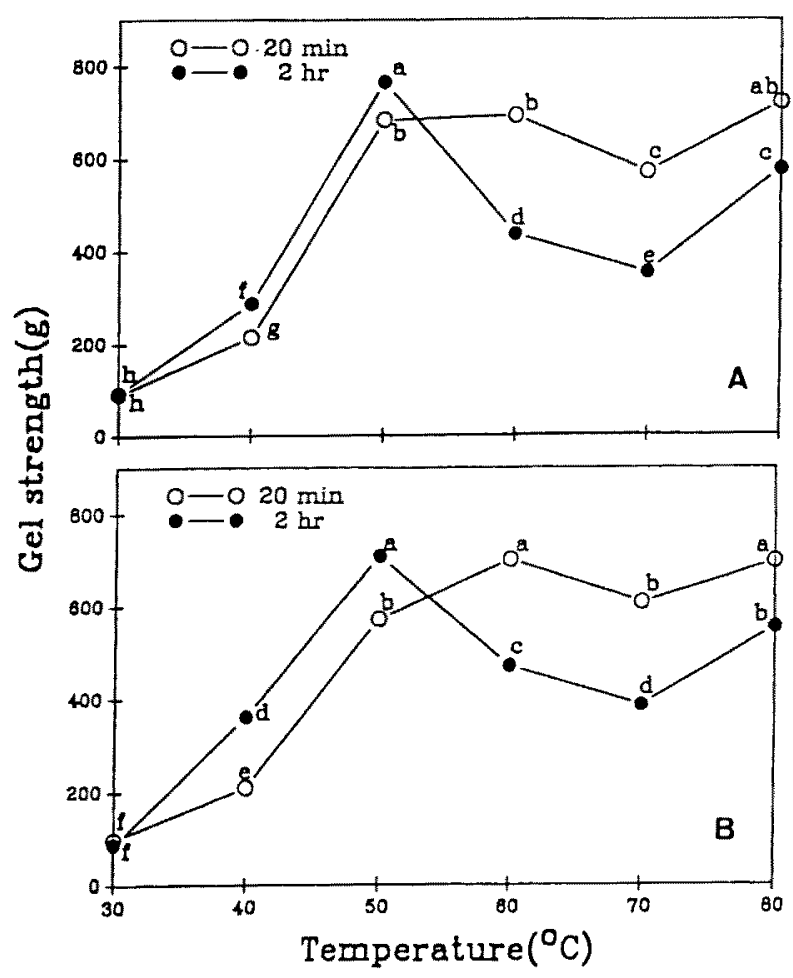

Fig. 5. Temperature-gelation curves of washed milkfish meat paste.

The meat pastes with or without Sp-P addition (moisture content $83 \%, \mathrm{pH} 6.8, \mathrm{NaCl} 2.5 \%$ ) were treated at different temperatures for 20 min or $2 \mathrm{~h}$ before measuring gel strength.

A: without $\mathrm{Sp}-\mathrm{P}$ addition. $\mathrm{B}$; with $\mathrm{Sp-P}$ addition.

Different letters $(a-h)$ adjacent to a value indicate a significant difference $(p<0.05)$ among values. its binding to myofibrillar proteins. ${ }^{11}$ From the standpoint of thermal gelation and water pollution, Sp-P removal is not necessary. On the other hand, the function of the Sp-P molecular weight below 30,000 and the characteristics of kamaboko gel with Sp-P addition must be investigated in detail. Whether or not the Sp-P of other fish species has the same effect also needs further research.

Acknowledgments This study was supported in part by research grants from the National Science Council, ROC, No. NSC 81-0406-E005-510.

\section{References}

1) X. Shimizu and F. Nishioka: Interactions between horse mackerel actomyosin and sarcoplasmic proteins during heat coagulation. Nippon Suisan Gakkaishi, 40, 231-234 (1974).

2) Y. Shimizu and F. Nishioka: Species variations in heat coagulation properties of fish actomyosin-sarcoplasmic proteins system. Nippon Suisan Gakkaishi, 40, 267-270 (1974).

3) Y. Shimizu, J. Shikata, and S. Fujioka: Effect of the press juice of fish muscle on the insolubilization of fish myofibril during frozen storage. Nippon Suisan Gakkaishi, 40, 271-274 (1974).

4) Y. Shimizu, S. Karata, and F. Nishioka: Extractability of proteins from fish skeletal muscle at low ionic strengths. Nippon Suisan Gakkaishi, 42, 1025-1031 (1976).

5) H. Niki, T. Kato, E. Deya, and S. Igarashi: Recovery of protein from effluent of fish meat in producing surimi and utilization of recovered protein. Nippon Suisan Gakkaishi, 51, 959-964 (1985).

6) K. Morioka and Y. Shimizu: Contribution of sarcoplasmic proteins to gel formation of fish meat. Nippon Suisan Gakkaisht, 56, 929-933 (1990).

7) K. Ninomiya, T. Ookawa, T. Tsuchiya, and J. J. Matsumoto: Concentration of fish water soluble protein and its gelation properties. Nippon Suisan Gakkaishi, 56, 1641 -1645 (1990).

8) D. Knorr: Effect of recovery methods on yield, quality and functional properties of potato protein concentration. J. Food Sci, 45, 1183-1186 (1983).

9) M. E. Mangino, Y. Y. Liao, N. J. Harper, C. V. Mort, and J. G. Zadow: Effect of heat processing on the functionality of whey protein 
concentrates. J. Food Sci., 52, 1522-1524 (1987).

10) C. Pallavicini: Effect of a proteolytic enzyme preparation (Alcalase) on whey protein. J. Dairy Sci., 71, 887-892 (1988).

11) K. Y. Peng and W. C. Chiang: Recovery of protein from the wastewater of mungbean starch noodle factory by adsorbitive bubble separation. Food Sci. (Taiwan), 8, 93-102 (1982).

12) W. C. Chiang and D. Y. Lin: Optimum conditions of steeping for the separation of mungbean starch and recovery of protein from mungbean milk. Food Sci. (Taiwan), 8, 103-117 (1982).

13) T. Ookawa, K. Ninomiya, K. Takahashi, T. Tsuchiya, and J. Matsumoto: Recovery of fish water-soluble protein as food material by addition of polymer coagulants. Nippon Suisan Gakkaishi, 58,
2089-2093 (1992).

14) W. C. Ko, M. S. Hwang, and W. J. Chen: Recovery of sarcoplasmic protein from milkfish by using an ultrafiltration unit. J. Agric. Fore (Taiwan) (in press).

15) SAS Institute, Inc. User's Guide: Statistics. SAS Institute, Cary, NC (1982).

16) Y. Shimizu, R. Machida, and S. Takenami: Species variations in the gel-forming characteristics of fish meat paste. Nippon Suisan Gakkaishi, 47, 95-99 (1981).

17) A. G. Gornell, C. J. Bardawill, and M. M. David: Determination of serum proteins by means of the biuret reaction. J. Biol. Chem., 177, 751-766 (1949). 